\title{
Expanding the chemical diversity of spirooxindoles via alkylative pyridine dearomatization
}

\author{
Chunhui Dai, Bo Liang and Corey R. J. Stephenson*
}

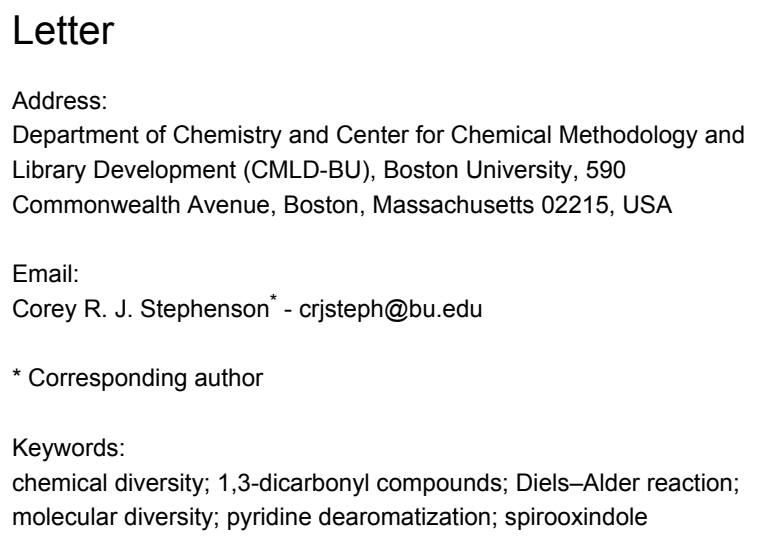

Beilstein J. Org. Chem. 2012, 8, 986-993.

doi:10.3762/bjoc.8.111

Received: 18 March 2012

Accepted: 31 May 2012

Published: 02 July 2012

This article is part of the Thematic Series "Recent developments in chemical diversity".

Guest Editor: J. A. Porco Jr.

(C) 2012 Dai et al; licensee Beilstein-Institut. License and terms: see end of document.

\begin{abstract}
A mild and practical synthesis of spirooxindole [1,3]oxazino derivatives from $N$-substituted isatins and 1,3-dicarbonyl compounds with pyridine derivatives is reported. The reactions provided good to excellent yields. Further exploration of the molecular diversity of these compounds is demonstrated through Diels-Alder reactions.
\end{abstract}

\section{Introduction}

The spirooxindole is a common structural motif found in a variety of complex alkaloids [1]. Many compounds that possess a spirooxindole moiety exhibit significant biological activity, thus exemplifying their role in drug development [2-8]. Moreover, the challenging molecular architecture of spirooxindoles is appealing to chemists because it evokes novel synthetic strategies that address configurational demands and provides platforms for further reaction development [9-11]. To our knowledge, most studies of these types of molecules focus on spirooxindoles bearing a pyrrolidine ring at the 3-position of the oxindole core, while few reports expand to formulate the syntheses of other spiro rings. As part of our ongoing reaction- screening objective $[12,13]$, we previously reported a Lewis acid catalyzed, three-component synthesis of spirooxindole pyranochromenedione derivatives using isatin and two 1,3dicarbonyl compounds (Scheme 1) [14]. Mechanistically, we believed this reaction to proceed through an intermediate isatylidene 1 [15-17]. As a means to support our mechanistic hypothesis, we attempted to prepare and isolate the isatylidene; however, our attempts were unsuccessful. Interestingly, treatment of 2 with methanesulfonyl chloride $(\mathrm{MsCl})$ in pyridine provided the dearomatized alkylation product 3 in $78 \%$ yield. In the context of developing novel and practical methods for the preparation of diverse heterocyclic compounds, herein, we 


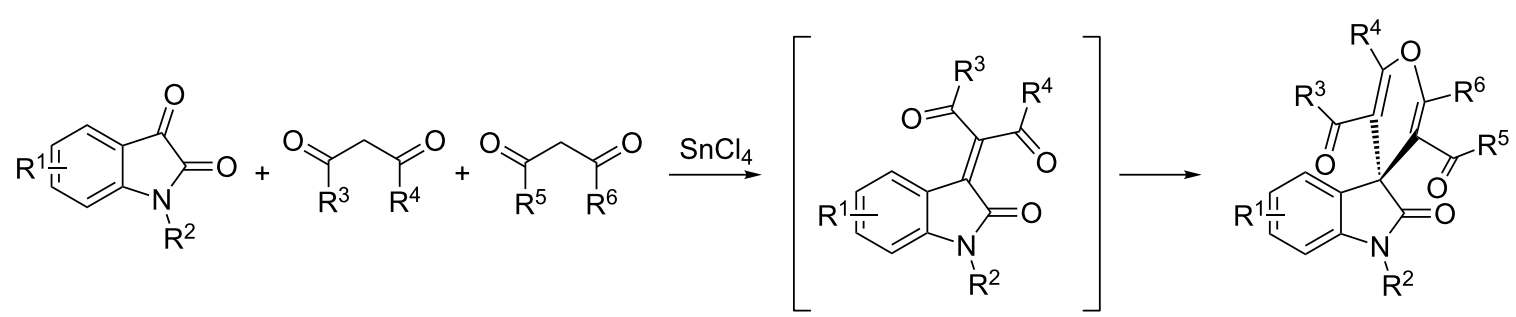

1<smiles></smiles>

2

$\mathrm{MsCl}$, pyridine<smiles>O=C1CCCC(=O)C1=C1C(=O)N([N+](=O)[O-])c2ccccc21</smiles>

not observed

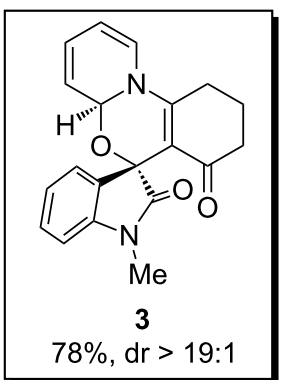

Scheme 1: Unexpected alkylative pyridine dearomatization during our previous work on the synthesis of spirooxindole pyranochromenediones.

report our extended investigation on the efficient synthesis of spirooxindole $[1,3]$ oxazino derivatives by means of alkylative pyridine dearomatization [18-21].

\section{Results and Discussion}

\section{Reactions of $\mathrm{N}$-substituted isatins and 1,3- dicarbonyl compounds in pyridine}

Based on preliminary results, we commenced with the reaction of $\mathrm{N}$-substituted isatins $\mathbf{4}$ and 1,3-dicarbonyl compounds $\mathbf{5}$ in pyridine. After addition of the reagents, the mixture was allowed to react at room temperature for $2 \mathrm{~h}$ to ensure initial coupling, whereupon methanesulfonyl chloride was added slowly over a $1 \mathrm{~h}$ period at $0{ }^{\circ} \mathrm{C}$ and another $2 \mathrm{~h}$ at the same temperature to trap the vinylogous acid as vinyl mesylates 6 . Various $N$-substituted isatins and 1,3-dicarbonyl compounds were then explored and the results are presented in Table 1. Beginning with isatin and 1,3-cyclohexanedione (5a) as coupling partners, we isolated a relatively poor yield of product 6a (Table 1, entry 1). We speculated that the free indole nitrogen was inhibiting the reaction, thus we switched to

Table 1: Reaction of isatins 4 and 1,3-dicarbonyl compounds 5 in pyridine.<smiles>[R1]N1C(=O)C(=O)c2cc[R1]cc21</smiles><smiles>O=C1CCCC(=O)C1</smiles>

5<smiles></smiles>

6

\begin{tabular}{|c|c|c|c|c|c|}
\hline entry $^{a}$ & $\mathrm{R}^{1}$ & $\mathrm{R}^{2}$ & 5 & product & $\begin{array}{l}\text { yield } \\
(\%)^{b}\end{array}$ \\
\hline
\end{tabular}
$\mathrm{H}$ $\mathrm{H}$<smiles>O=C1CCCC(=O)C1</smiles>

$5 a$<smiles></smiles>

$6 a$ 
Table 1: Reaction of isatins 4 and 1,3-dicarbonyl compounds 5 in pyridine. (continued)

$2 \quad \mathrm{Me} \quad \mathrm{H}$

$5 a$<smiles>COC1=C(C2(O)C(=O)N(C)c3ccccc32)C(=O)CCC1</smiles>

6b

$5 a$<smiles>COC1=C(C2(O)C(=O)N(C)c3ccc(C)cc32)C(=O)CCC1</smiles>

6c<smiles>COC1=C(C2(O)C(=O)N(C)c3ccc(Cl)cc32)C(=O)CCC1</smiles>

6d<smiles>COC1=C(C2(O)C(=O)N(C)c3ccc([N+](=O)[O-])cc32)C(=O)CCC1</smiles>

$6 e$<smiles>CC1(C)CC(=O)CC(=O)C1</smiles>

$5 b$<smiles>COC1=C(C2(O)C(=O)N(C)c3ccccc32)C(=O)CC(C)(C)C1</smiles>

$6 f$<smiles>COC1=C(C2(O)C(=O)N(C)c3ccccc32)C(=O)CC(c2ccccc2)C1</smiles>

$6 \mathrm{~g}$<smiles>COC1=C(C2(O)C(=O)N(C)c3ccccc32)C(=O)C(C)(C)CC1</smiles>

80

57

84

89

87

61 
Table 1: Reaction of isatins 4 and 1,3-dicarbonyl compounds 5 in pyridine. (continued)

9

$\mathrm{Ph}$

$\mathrm{H}$

$10^{c}$
Ac

$\mathrm{H}$
$5 a$<smiles>COC1=C(C2(O)C(=O)N(c3ccccc3)c3ccccc32)C(=O)CCC1</smiles>

6i<smiles>CN1C(=O)C(=C2C(=O)CCCC2=O)c2ccccc21</smiles>

a Reactions were carried out on a $10 \mathrm{mmol}$ scale in pyridine $(8.0 \mathrm{~mL})$ with 1.0 equiv of isatins $\mathbf{4}$ and 1,3 -dicarbonyl compounds $\mathbf{5}$ at room temperature for $2 \mathrm{~h}$, followed by the addition of 1.5 equiv of $\mathrm{MsCl}$ at $0{ }^{\circ} \mathrm{C}$ over $1 \mathrm{~h}$ and another $2 \mathrm{~h}$ stirring at the same temperature. ${ }^{\mathrm{b}} / \mathrm{solated}$ yield. ${ }^{\mathrm{C}} \mathrm{The}$ adduct $6 \mathrm{j}$ was isolated as the only product.

$N$-substituted isatins and found that the reaction improved to provide moderate to high yields (Table 1, entries 2-10). Subtle substitution effects were observed when the $\mathrm{C}(5)-\mathrm{H}$ of isatin was replaced with various functionalities. Specifically, an electron-donating group at the 5-position, such as a methyl group, decreased the reactivity and only gave $57 \%$ yield (Table 1 , entry 3). As a comparison, electron-withdrawing groups at the 5-position, such as chloro and nitro groups, increased the reactivity and provided products in higher yield (Table 1, entries 4-5). Other 1,3-dicarbonyl compounds were also investigated. 5,5-Dimethyl-1,3-cyclohexanedione (5b) worked well (Table 1, entry 6), in contrast to 5-phenyl-1,3-cyclohexanedione (5c), which gave a slightly lower yield (Table 1, entry 7). Interestingly, nonequivalent 1,3-dicarbonyl compound 5d afforded single constitutional isomer (Table 1 , entry 8 ), presumably due to the increased sterics and overall ring strain associated with substituents alpha to the vinylogous sulfonyl ester. $N$-Phenylisatin provided a similar yield to $N$-methylisatin (Table 1, entry 9). However, when $N$-acetylisatin was subjected to the reaction conditions, the reaction failed to provide the desired product and instead delivered compound $\mathbf{6 j}$ exclusively in $74 \%$ yield (Table 1, entry 10). We predict that the formation of $\mathbf{6 j}$ by dehydration is due to the electron deficiency of the oxindole ring and subsequent stability gained from the ene-trione moiety. The structure of compound $\mathbf{6 b}$ was established by single-crystal X-ray analysis (Figure 1).

Having established a facile route to our desired vinylogous sulfonyl esters $\mathbf{6}$, we next examined their reactivity towards alkylative pyridine dearomatization reactions (Table 2). During optimization studies, we discovered that the reaction performed

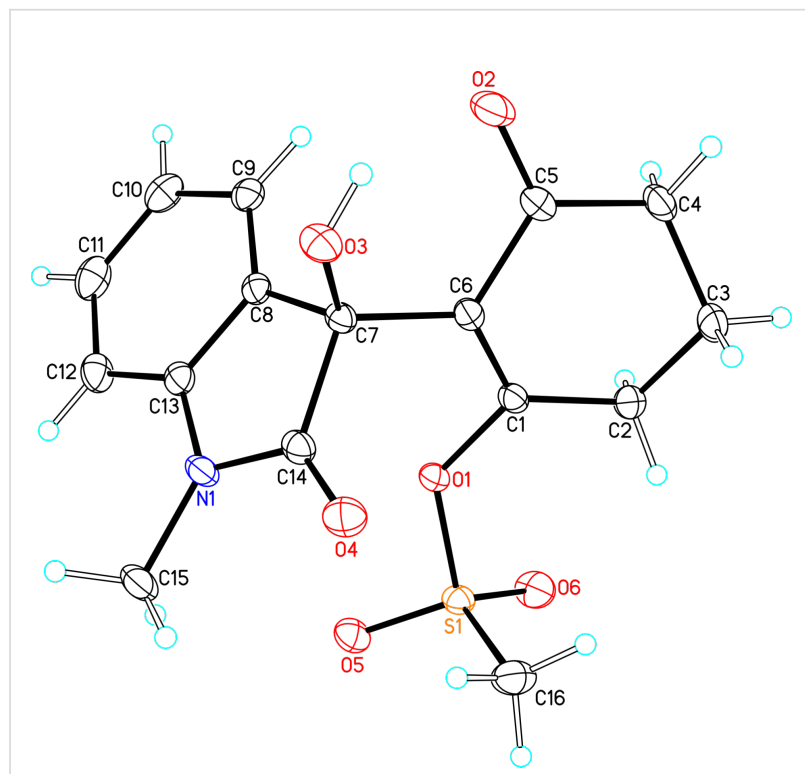

Figure 1: X-ray crystal structure of compound $\mathbf{6 b}$.

best at $45{ }^{\circ} \mathrm{C}$ using pyridine as the solvent. The substituent groups on the isatin moiety did not have a great effect on the reactivity of compounds 6 . Generally, the reaction was complete in $12 \mathrm{~h}$ and provided inseparable diastereoisomers with good to excellent yields (Table 2, entries 1-5). 4-Picoline (7b) gave a lower yield after $12 \mathrm{~h}$ at $45{ }^{\circ} \mathrm{C}$ (Table 2, entry 6). 4-Methoxypyridine $(7 \mathbf{c})$ provided the desired product $3 \mathrm{~g}$ in $78 \%$ isolated yield in only $6 \mathrm{~h}$ at room temperature (Table 2, entry 7 ). Isoquinoline (7d) and 4-acetylpyridine (7e) also underwent the reaction to provide the desired products in moderate yields 
Table 2: Reactions of vinylogous sulfonyl esters 6 with pyridine derivatives 7 .

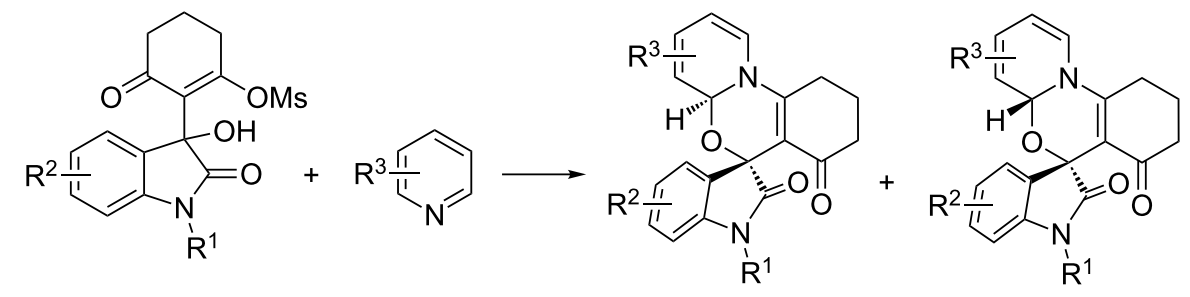

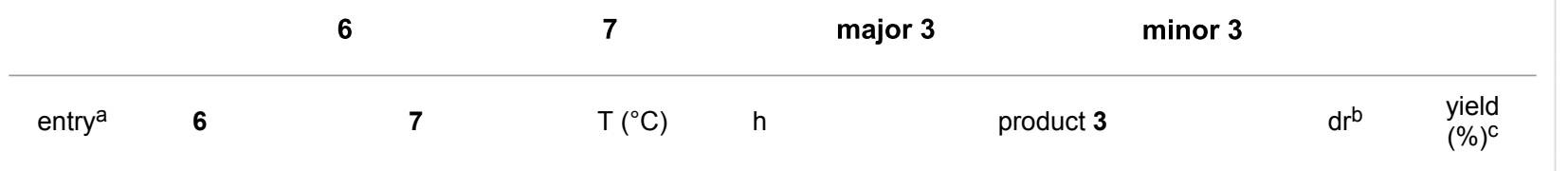

$16 b$

$26 c$

$7 a$<smiles>c1ccncc1</smiles>

45

12

45

12<smiles>CN1C(=O)C2(O[C@@H]3C=CC=CN3C3=C2C(=O)CCC3)c2ccccc21</smiles>

$3 a$<smiles>Cc1ccc2c(c1)[C@@]1(OC[C@H]3C=CC=CN3C3=C1C(=O)CCC3)C(=O)N2C</smiles>

3b<smiles>CN1C(=O)[C@]2(O[C@@H]3C=CC=CN3C3=C2C(=O)CCC3)c2cc(Cl)ccc21</smiles>

$7: 1 \quad 90$<smiles>CN1C(=O)[C@@]2(O[C@H]3C=CC=CN3C3=C2C(=O)CCC3)c2cc([N+](=O)[O-])ccc21</smiles>

3d<smiles>O=C1CCCC2=C1[C@]1([C@H]3C=CC=CN3)OC2N(c2ccccc2)c2ccccc21</smiles>

$\mathrm{Ph}$
$5: 1 \quad 90$

$9: 1 \quad 83$

$5: 1 \quad 91$

$5: 1 \quad 74$
5

$6 i$

$7 a$

$45 \quad 12$ 
Table 2: Reactions of vinylogous sulfonyl esters 6 with pyridine derivatives 7. (continued)

6

$6 b$<smiles>Cc1ccncc1</smiles>

7

$6 b$<smiles>COc1ccncc1</smiles>

8

$6 b$<smiles>c1ccc2cnccc2c1</smiles>

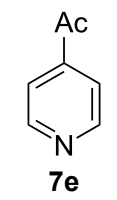

60

18

45

12

23

6<smiles>CC1=C[C@H]2O[C@@]3(C(=O)N(C)c4ccccc43)C3=C(CCCC3=O)N2C=C1</smiles>

$3 f$<smiles>COC1=C[C@H]2O[C@@]3(C(=O)N(C)c4ccccc43)C3=C(CCCC3=O)N2C=C1</smiles>

$3 \mathrm{~g}$<smiles>CN1C(=O)[C@]2(O[C@@H]3C=c4ccccc4=CN3C3=C2C(=O)CCC3)c2ccccc21</smiles>

3h<smiles>CN1C(=O)[C@@]2(O[C@@H]3C=C(C4CCCC4)C=CN3C3=C2C(=O)CCC3)c2cc(Cl)ccc21</smiles>

$8: 1$

48

$3: 1$

78

$2: 1$

65

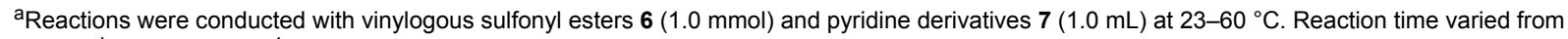
$6-18 \mathrm{~h}$. ' ${ }^{6}$ Determined by ${ }^{1} \mathrm{H}$ NMR integration. CIsolated yield.

(Table 2, entries 8-9), but required an elevated temperature $\left(60^{\circ} \mathrm{C}\right)$ and a longer reaction time $(18 \mathrm{~h})$. On the basis of the results in Table 2, we speculate that the unexpected formation of compound 3 in Scheme 1 was due to the evaporation of solvent after the reaction at elevated temperature $\left(45^{\circ} \mathrm{C}\right)$, providing an opportunity for the vinylogous sulfonate ester, generated during the reaction, to react with pyridine. Finally, the structure of compound 3d was established by single-crystal $\mathrm{X}$-ray analysis (Figure 2).

Further plans to expand the molecular diversity of these compounds utilizing available functionalities are currently underway. As an illustrative example, spiro [1,3]oxazino compounds having a diene moiety within their molecular framework are susceptible to Diels-Alder (D-A) reactions [22].
Scheme 2 highlights three examples in which compound 3a was exposed to $N$-substituted maleimides in toluene at $150{ }^{\circ} \mathrm{C}$ under microwave irradiation for $0.5 \mathrm{~h}$, and $\mathrm{D}-\mathrm{A}$ products $8 \mathbf{8}-\mathbf{c}$ were isolated in moderate yields. Finally, the structure of compound 8a was established by single-crystal X-ray analysis (Figure 3).

\section{Conclusion}

In summary, we developed a practical and efficient method to synthesize spirooxindole derivatives with a $[1,3]$ oxazine fusedring system. The reaction conditions are very mild and tolerant of functional groups, providing moderate to high yields. The application and versatility of these spirooxindole derivatives to quickly access complex molecules is further demonstrated in good yielding D-A reactions. 


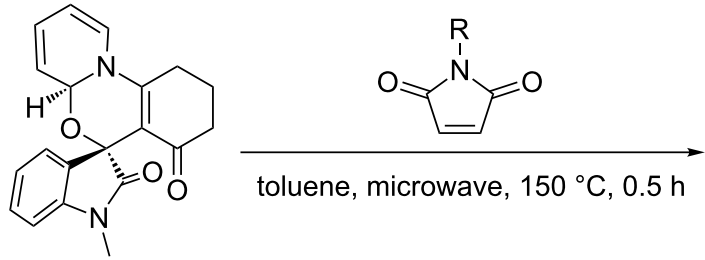

$3 a$

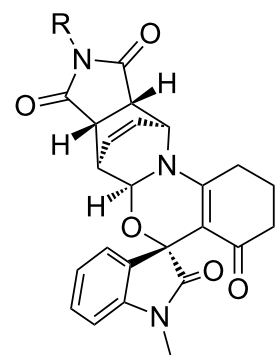

$\mathrm{R}=\mathrm{Me}: \mathbf{8} \mathbf{a}(67 \%)$

$\mathrm{R}=\mathrm{Ph}: \mathbf{8} \mathbf{b}(70 \%)$

$\mathrm{R}=\mathrm{Bn}: \mathbf{8 c}(60 \%)$
$[4+2]$ model:

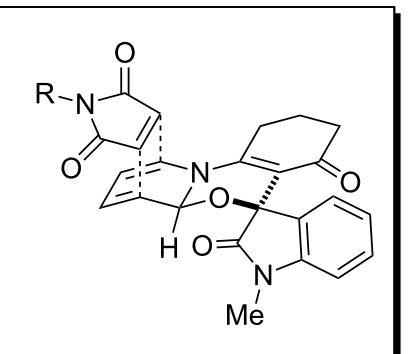

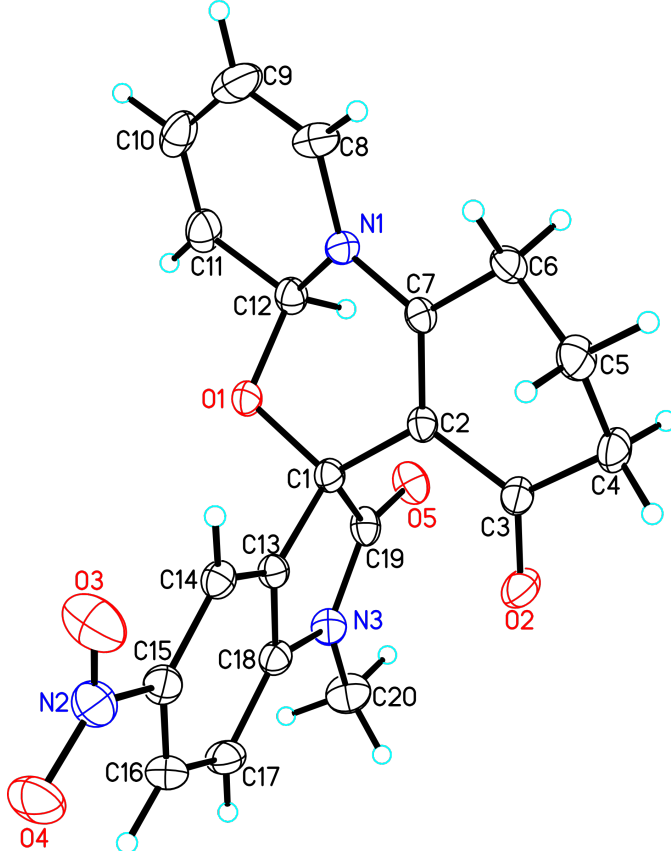

Figure 2: X-ray crystal structure of compound $\mathbf{3 d}$.

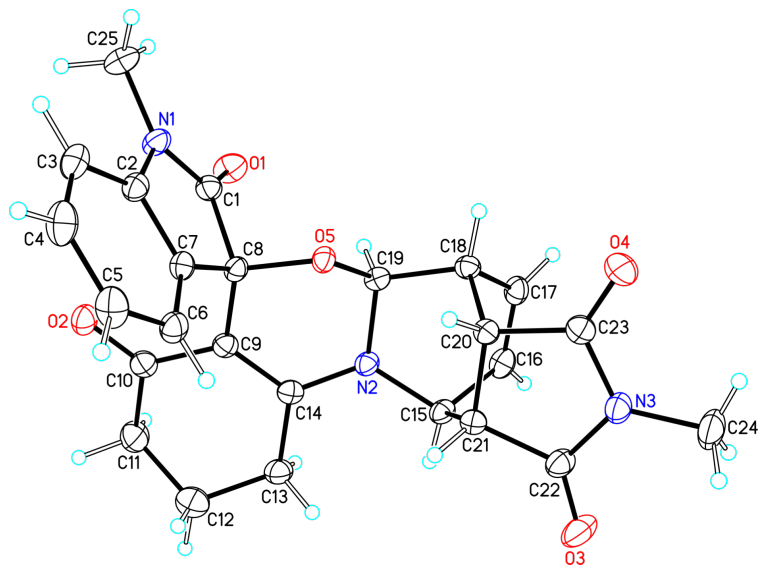

Figure 3: X-ray crystal structure of compound $\mathbf{8 a}$.

\section{Supporting Information}

\section{Supporting Information File 1}

Full experimental details and analytical data and crystallographic information.

[http://www.beilstein-journals.org/bjoc/content/ supplementary/1860-5397-8-111-S1.pdf]

\section{Acknowledgements}

Financial support for this research from the NIH-NIGMS (P50GM067041), NSF (CHE-1056568), the Alfred P. Sloan Foundation, Amgen, Boehringer Ingelheim, and Boston University is gratefully acknowledged. C.D. thanks AstraZeneca for a graduate fellowship. NMR (CHE-0619339) and MS (CHE0443618) facilities at BU are supported by the NSF. The authors are grateful to Professor John Porco (Boston University) for helpful discussions.

\section{References}

1. Bindra, J. S. In The Alkaloids; Manske, R. H. F., Ed.; Academic Press: New York, 1973; Vol. 14, pp 84-121.

2. Onishi, T.; Sebahar, P. R.; Williams, R. M. Tetrahedron 2004, 60, 9503-9515. doi:10.1016/j.tet.2004.07.047

3. Onishi, T.; Sebahar, P. R.; Williams, R. M. Org. Lett. 2003, 5, 3135-3137. doi:10.1021/ol0351910

4. Sebahar, P. R.; Williams, R. M. J. Am. Chem. Soc. 2000, 122, 5666-5667. doi:10.1021/ja001133n

5. Alper, P. B.; Meyers, C.; Lerchner, A.; Siegel, D. R.; Carreira, E. M. Angew. Chem., Int. Ed. 1999, 38, 3186-3189. doi:10.1002/(SICI)1521-3773(19991102)38:21<3186::AID-ANIE3186>3 .0.CO;2-E

6. Edmondson, S.; Danishefsky, S. J.; Sepp-Lorenzino, L.; Rosen, N. J. Am. Chem. Soc. 1999, 121, 2147-2155. doi:10.1021/ja983788i

7. Matsuura, T.; Overman, L. E.; Poon, D. J. J. Am. Chem. Soc. 1998, 120, 6500-6503. doi:10.1021/ja980788+

8. Ashimori, A.; Bachand, B.; Overman, L. E.; Poon, D. J. J. Am. Chem. Soc. 1998, 120, 6477-6487. doi:10.1021/ja980786p

9. Trost, B. M.; Brennan, M. K. Synthesis 2009, 18, 3003-3025. doi:10.1055/s-0029-1216975 
10. Galliford, C. V.; Scheidt, K. A. Angew. Chem., Int. Ed. 2007, 46, 8748-8758. doi:10.1002/anie.200701342

11. Marti, C.; Carreira, E. M. Eur. J. Org. Chem. 2003, 2209-2219. doi:10.1002/ejoc.200300050

12. Beeler, A. B.; Su, S.; Singleton, C. A.; Porco, J. A., Jr. J. Am. Chem. Soc. 2007, 129, 1413-1419. doi:10.1021/ja0674744

13. Balthaser, B. R.; Maloney, M. C.; Beeler, A. B.; Porco, J. A., Jr.; Snyder, J. K. Nat. Chem. 2011, 3, 969-973. doi:10.1038/nchem.1178

14. Liang, B.; Kalidindi, S.; Porco, J. A., Jr.; Stephenson, C. R. J. Org. Lett. 2010, 12, 572-575. doi:10.1021/ol902764k

15. Yin, X.-G.; Liu, X.-Y.; Hu, Z.-P.; Yan, M. Org. Biomol. Chem. 2012, 10, 1506-1509. doi:10.1039/C2OB06995D

16. Deng, H.-P.; Wei, Y.; Shi, M. Org. Lett. 2011, 13, 3348-3351. doi:10.1021/ol201094f

17. Hari Babu, T.; Joseph, A. A.; Muralidharan, D.; Perumal, P. T. Tetrahedron Lett. 2010, 51, 994-996. doi:10.1016/j.tetlet.2009.12.082

18. Roche, S. P.; Porco, J. A., Jr. Angew. Chem., Int. Ed. 2011, 50, 4068-4093. doi:10.1002/anie.201006017

19. Nair, V.; Devipriya, S.; Suresh, E. Tetrahedron 2008, 64, 3567-3577. doi:10.1016/j.tet.2008.01.106

20. Yavari, I.; Mokhtarporyani-Sanandaj, A.; Moradi, L. Tetrahedron Lett. 2007, 48, 6709-6712. doi:10.1016/j.tetlet.2007.07.135

21. Nair, V.; Sreekanth, A. R.; Abhilash, N.; Biju, A. T.; Devi, B. R.; Menon, R. S.; Rath, N. P.; Srinivas, R. Synthesis 2003, 1895-1902. doi:10.1055/s-2003-41000

22. Diels, O.; Alder, K. Liebigs Ann. Chem. 1928, 460, 98-122. doi:10.1002/jlac.19284600106

\section{License and Terms}

This is an Open Access article under the terms of the Creative Commons Attribution License (http://creativecommons.org/licenses/by/2.0), which permits unrestricted use, distribution, and reproduction in any medium, provided the original work is properly cited.

The license is subject to the Beilstein Journal of Organic Chemistry terms and conditions:

(http://www.beilstein-journals.org/bjoc)

The definitive version of this article is the electronic one which can be found at: $\underline{\text { doi:10.3762/bjoc.8.111 }}$ 